明石海峡上空風速の写真測量的測定

$\begin{array}{lll}\text { 笠松 } & \text { 清* } \\ \text { 中村貞 治* }\end{array}$

\title{
Photogrammetric Measurements of the Wind Velocity over the Straits of Akashi
}

By Kiyoshi Kasamatsu \&

Koji Nakamura

Report of a test on photogrammetric measurements of the wind velocity at several altitudes over the Straits of Akashi to determine the local of changes wind is described.

Photographs are taken by simultaneous photographing the fireworks, provided parachutes, with two phototheodolites placed at the stations on the base line, at night.

Stereophotographs are measured with the first order stereoplotter.

まえがき 本士と四国を結ぶ“夢のかけ橋”の基礎 淍查段階として，この度海底地質調查等と共に海峡上 架の気像観測が建設少化頼で父像宁によつて行われる こととなつた。今间山普通に用いられている風船と測 風経緯儀とで観測する方法が行わ机たことは勿論であ 万)

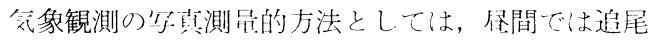

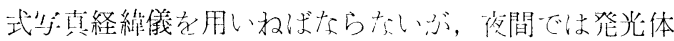
を飛ばせげ国定式年真経緯儀でも良く，発光体と風船 で飛ばして行つた F.W. Hifze の例(1)などがある。

我々の分担したう法は一䇥高度每に落下金附発火花 火を同時に数発打ち掦げ，シヤッタ一開放の一対の[四 定式等真経緯儀で立体撮影し，発光体の風に流され石

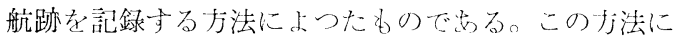

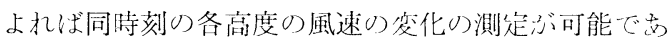
\%)

少真経緋儀の同㮮な応用例として発光運動物体を同 時撮影する方法をとつたものに，Ballistic Camera (2) による弾道の研究が女り, 又東京大学生産技術研究所 丸安研究室及び植村研究公で行われた口グット弾道の 研究 ${ }^{(3)}$ には, 括尾式乞国定式の特殊カメラが用いられ た。

筆者達の試験実施後人厅した文献によると W. E. Boge 氏の行つた試験(4) は成腼圈にまで達する超高空 の風速測定のためロケットによるVaper trail そ肎真 測甾的に記録測定したもので，末ことに大がかりなも のである。これに比較す机ばこの試験は小規模なるの

* |网蔡航業株式会社
で怘るが，超低空の局地風の父象観測の写真測昆的力 洪としては初めてではないかと考光る。そしてこの才 法は四的にかない適切な方法で如つたと考觉られ，己 り試験結果为良好で出つたのでここに天の大略を報 告士る次第で苦る。

\section{1. 試験の実施}

\section{1-1. 試験の方法}

落下傘附発光花火希望位置の希望高度で同時に発 光するようにするために归道学によつて次の如くに計 算決定した。先ず高度と射程とを出来るだけ大きくな 名5\%射角を第 1 図の如〈に求好て射角 $60^{\circ}$ と決定 し，次で $50 \mathrm{~m}$ 每の高度で 6 秒の経過時間で同時に発光 †石ための予想弹道側視図は第 2 四の通りで初速（薬 话）㖄咸によつて得られる。

またそり方问角は風向，撮影点，撮影四角之の関係 童考慮して撰び，予期したい風向等の変化にも即応し 得るようにした。

かくして $50 \mathrm{~m}$ 高度から $250 \mathrm{~m}$ まで50m 間隔で同時に 発光するように 5 発の花火を同時に打揚げた。第 3 図

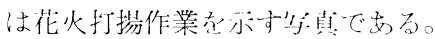

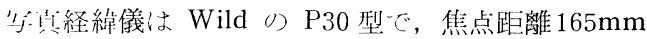
乾板り大きさ $100 \times 150 \mathrm{~mm}$, 口径比 $1 / 12$, 上下には迎

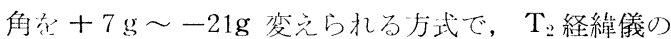
取附けられた斗ので，これ学2台適当の其線比で据党 た。单のタマーとしては 2 台同時に一定間隔時間で 作動するシナツターで撮影された航跡に切目をつける よ5に寸れで理想的で女るが，その余裕がなかつたの で，其潐となる1台にのみ等さ机る航跡に 5 秒間隔の 
筑 1 网花火弾道図

$$
\begin{gathered}
y=x \tan -g x^{2} \\
2 V_{1}^{2} \cos ^{2} \zeta \\
y=x \tan \varphi-4 x^{2} \cos ^{2} \zeta \\
x=\frac{V_{11}^{2} \sin ^{2} \zeta}{g}
\end{gathered}
$$

切目圭つけられ光ようにした。

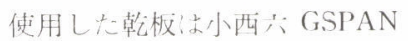
总用い, そ0感度: ASA 50 で まる。

其線測星には土地が平担だ在 かつたので, $2 \mathrm{~m}$ 測桿と $\mathrm{T}_{2}$ で

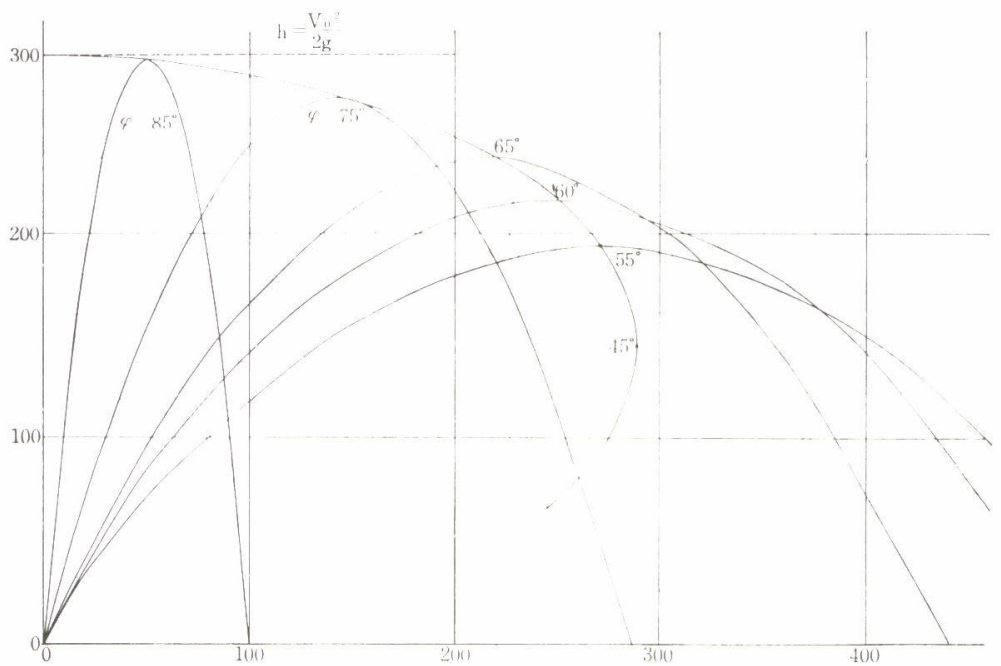
行つた。その撮影状態の関係壮

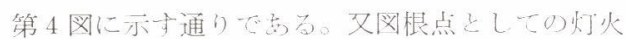

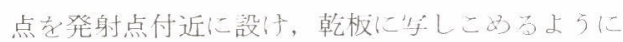
した。

\section{1-2. 予 備 試 験}

現地本試験の前に花火の撮等濃度等の試験のた

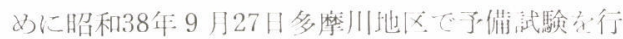

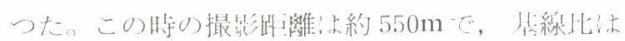
約 $1 / 11$ で口て

風向は媔度乾板獚に流扎方状態厄, 風速は約 $5 \mathrm{~m} / \mathrm{sec}$ 一古つた

\section{1-3. 図上計画と現地踏査}

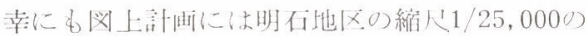

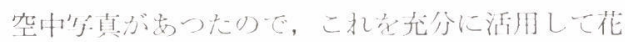
火打掦点及び撮影点の撰定在机上で行つて，犰 圭現地踏查で確認した。撮影点として等線ぶ无分 とれる高台足決定することが出来た。

\section{1-4. 本 試 験}

本試験に法最䖝風の吹く時期と乙一昭和39年 1 月26日，27日ぶ撰ばれたここの時の撮影距離は ほぼ1,100m〜1,300mで，继線比法約 $1 / 8$ 1/9 支つた。風向は西風の等が北風となつて撮影方向 に流れる結果となつた。

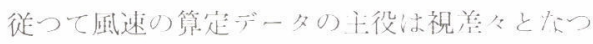
た。風速子数十米の笽が約 $10 \mathrm{~m} / \mathrm{sec}$ に過ぎ/か心

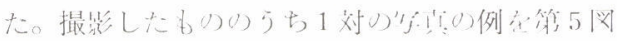
に示した。

\section{2. 試験結果}

\section{2-1. 風向風速の測定}

ネガ乾板长ステレオブラニグラフC8にかけ,

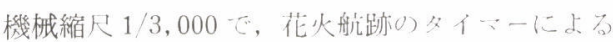

第 2 网 射角 60 において経過時間 6 秒の場合の発火点位置

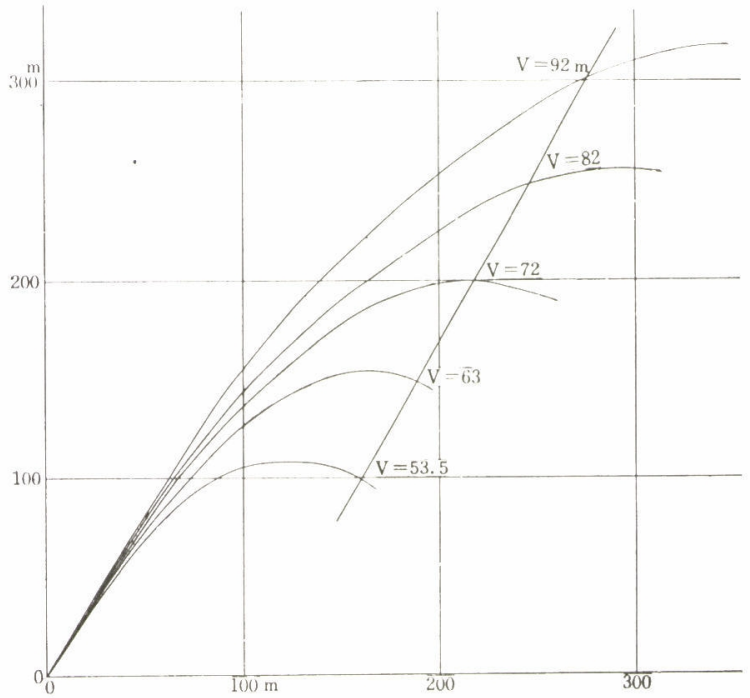

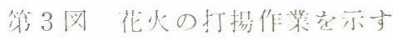
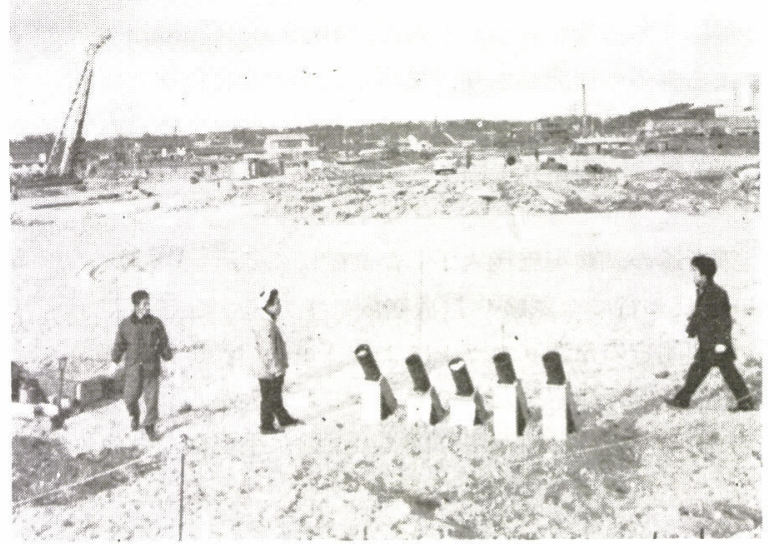


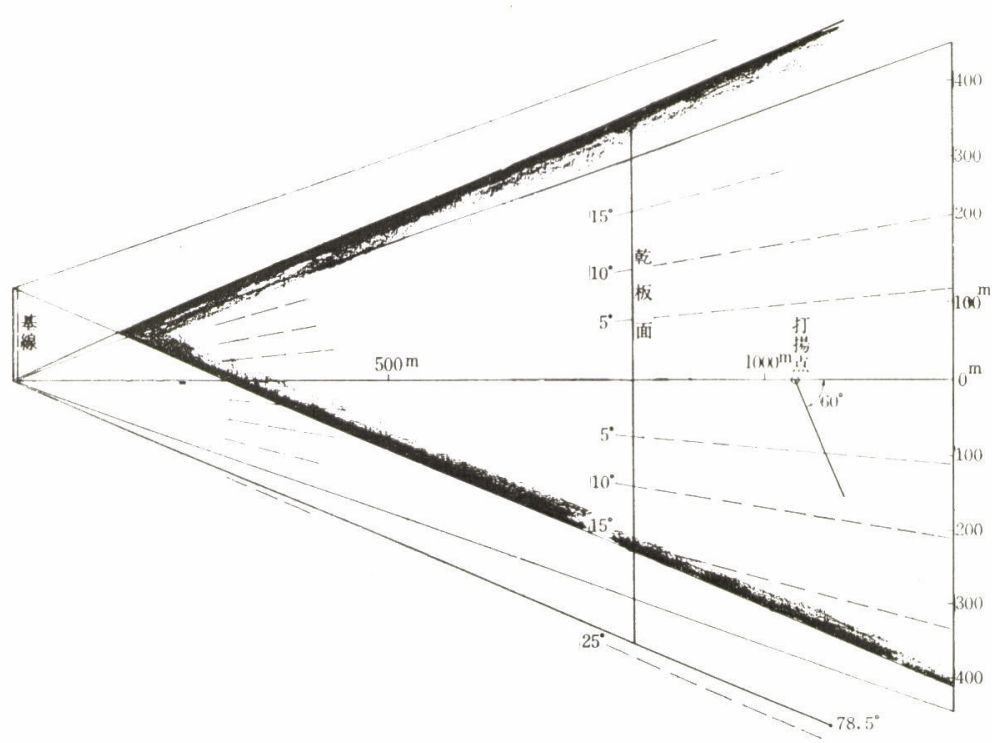

第 4 网撮影関係図

第 5 因化火休家真の一例

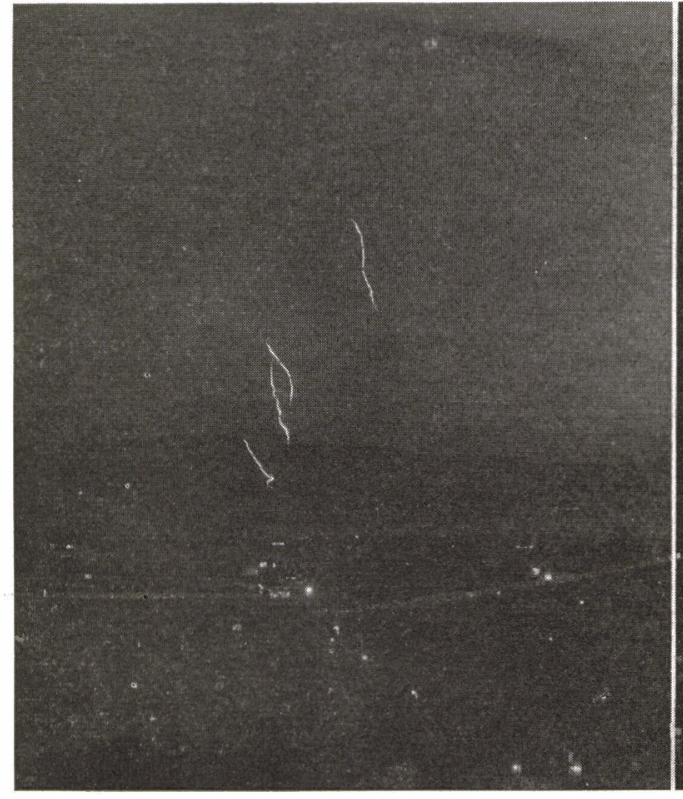

切目の坐標值老測定印字し, これからアフイン変換, 座標変換等の甜算拠理によつて, 高度, 風速, 風向等 を求めた。第 5 図の例の真刘から求めた結果の一部 は次頁の表の通りで女る。

又この例のものの花火航跡の切目座標測定結果の平 面図は第 6 図に示可通りで・印は図根となる灯火点を 示す。この点より北 $1 \mathrm{~km} の$ 所に撮影点がある。

\section{2-2. 精 度}

撮影力向が基線に垂直で平行な撮影の場合, 撮影条 件圭定めるための䛊差式は一般のテキストブック(5)に

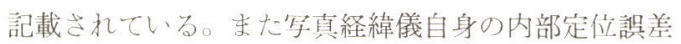
及びそれを設置する時の誤差については，今は亡き

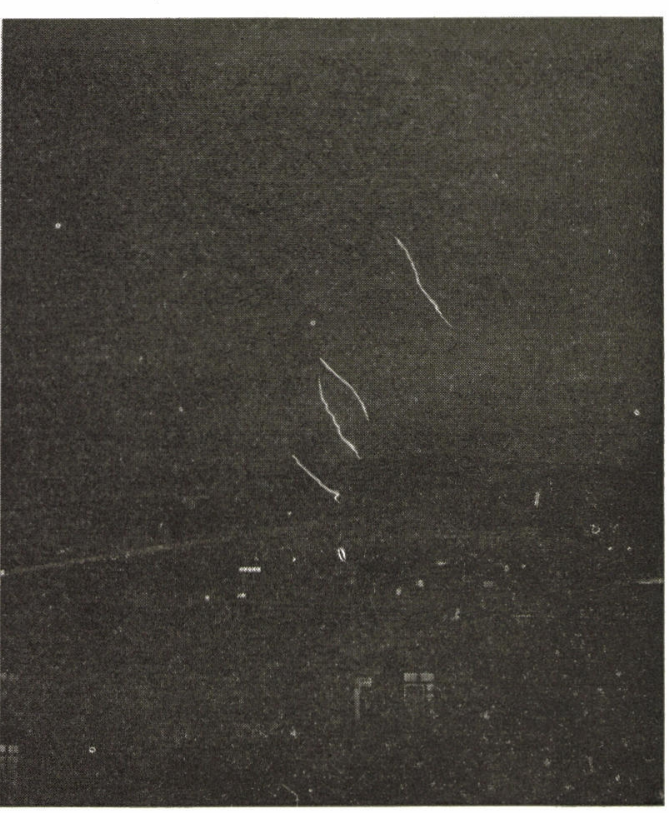

R. Finsterwalder 博士の著書(6)に論じられている。 これらを基礎として今回の試験の精度の中等䛊差老計 算すると次の通りである。

$$
\begin{array}{lll}
\text { 平 } & \text { 風 速 } & \pm 10 \mathrm{~cm} / \mathrm{sec} \\
\text { 高 } & \text { 度 } & \pm 20 \mathrm{~cm} \\
\text { 方 } & \text { 位 } & \pm 15^{\prime}
\end{array}
$$

\section{2-3. 試験の結果}

本武験では風向風速とも予報に反する気像状態とな つた。また同時に打揚げた落下金発火花火の中には落 下食が閒かないため落下してしま5もの子生じ, 発火 高度は予期する高度に達しなからた。

以上の覀柄は写真測量的に観測する側にとつては, 


\begin{tabular}{|c|c|c|c|c|c|c|c|}
\hline & $\begin{array}{l}\text { 脚㐨(D) } \\
\mathrm{m}\end{array}$ & $\begin{array}{l}\mathrm{D} / 5^{\prime \prime} \\
\mathrm{m} / \mathrm{sce}\end{array}$ & $\begin{array}{c}\text { 平圴塪速 } \\
\mathrm{m} / \mathrm{sec}\end{array}$ & $\underset{n}{F-D}$ & 蓠 $\mathrm{m}$ 度: & $\begin{array}{c}\text { 平的高度 } \\
\mathrm{m}\end{array}$ & $f_{j}$ \\
\hline II & I & & & & & & \\
\hline 1.2 & 18.8 & 9.7 & \multirow{2}{*}{9.4} & 0.3 & $\begin{array}{l}207.81 \\
197.49\end{array}$ & 202.65 & $10^{\prime} 14^{\prime}$ \\
\hline $2-3$ & 90.5 & 9.1 & & 0.3 & 181.71 & 189.60 & $1624^{\prime}$ \\
\hline 12 & 44.2 & 8.8 & \multirow[t]{2}{*}{8.5} & 0.3 & $\begin{array}{l}130.77 \\
121.50\end{array}$ & 126.14 & $18^{\circ} 44^{\prime}$ \\
\hline $2-3$ & 82.2 & 8.2 & & 0.3 & 107.04 & 114.27 & $9-04^{\prime}$ \\
\hline
\end{tabular}

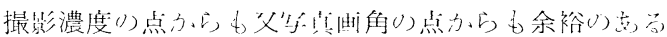

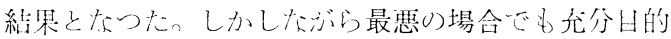

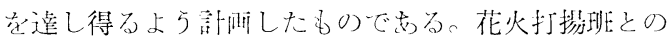

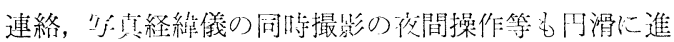

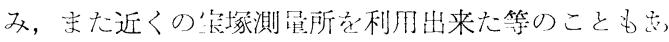
つて, 充分厅精度で一枚の無䭾撮影视次く廷施出来た

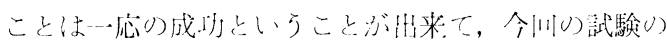
日的い如き場合に有效な”真測量的于法を呈示し得た ものと信ずるものである。

今回の如く水平上り上を撮影する場合写真経緯儀の 雨角は上り広角であるか迎角を多くかけられるのが有 利で，この点前記 W.E. Boge 氏の試験(4)の場合には

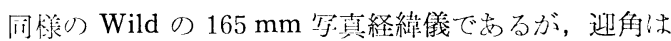
+12g米でかけられるもので有利であつたと考兄られ \%。

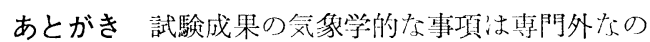
で除外した。気象現象一花火一写真測最とを結ぶ尩真 測是応用の一つのかけ橋学実施し御指導して頂いた気 象研究所, 高橋喜彦博士，また花火打揚げに御無理を 愿つ心細谷火工株式会社, 服部一郎工場長, また種々 御便宜と御助言と学頂いた生産技術研究所丸安隆和教 授派ざに大島先生，作業に協力して頂いた国際航業の カィに対して深く感謝与る次第である。

\section{参考文献}

(1) O. Lacmann; "Die Photogrammetrie in ihrer Anwendung auf nicht-topographischen Gebieten” 1950. P. 132

(2) M. Zeller; "Lehrbuch der Photogrammetrie" 1946. P. 97

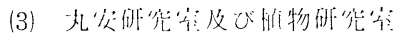

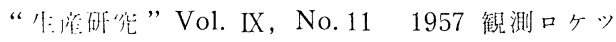
卜特集号

(4) W. E. Boge; "Upper Atomospheric Wind Determinations from Stereo-photography of Rocket Vapor Trails" "Photogrammetric Engineering" Vol XXIX. 1963. P. 1059-1067
(5) -.. 例

K. Schwidefsky; "Groundriss der Photogrammetrie" 6 Auf. 1963. P.31

(6) R. Finsterwalder; "Photogrammetrie" 2-Auf 1952 P. 105-109

符６刚各高度の風速風向図の一例
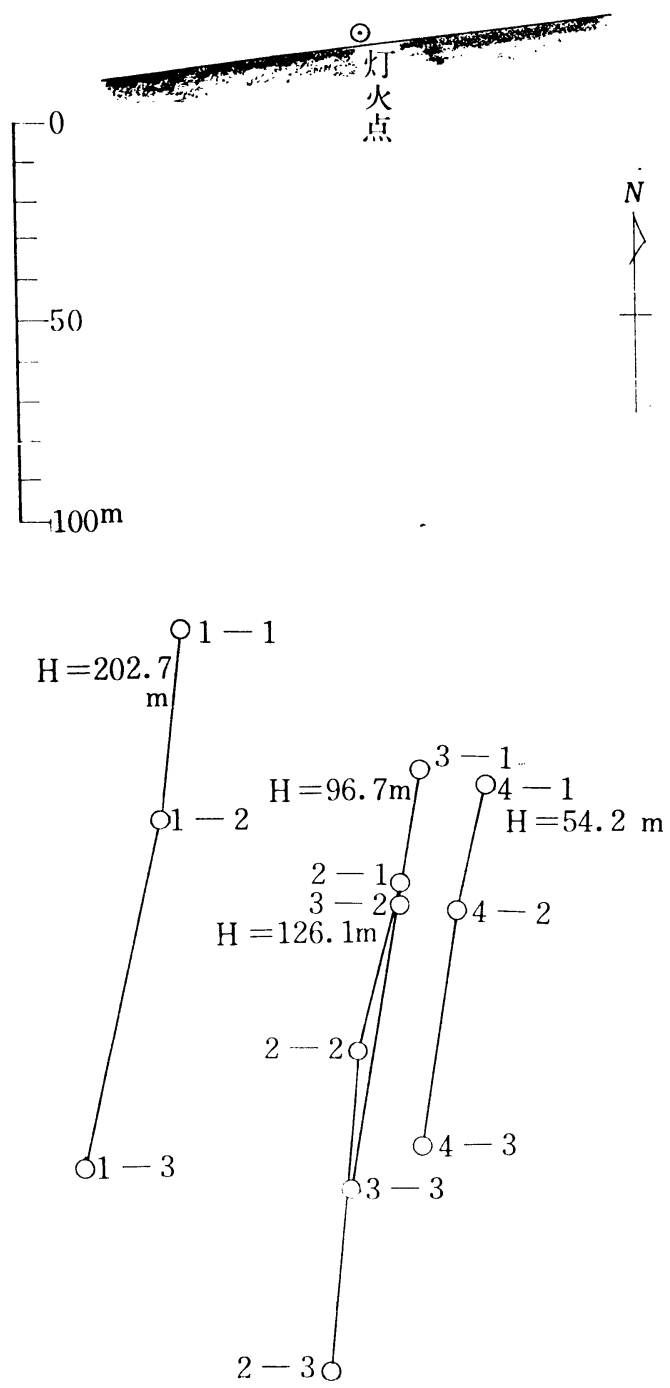